

\section{DISCLAIMER}

This report was prepared as an account of work sponsored by an agency of the United States Government. Neither the United States Government nor any agency thereof, nor any of their employees, make any warranty, express or implied, or assumes any legal liability or responsibility for the accuracy, completeness, or usefulness of any information, apparatus, product, or process disclosed, or represents that its use would not infringe privately owned rights. Reference herein to any specific commercial product, process, or service by trade name, trademark, manufacturer, or otherwise does not necessarily constitute or imply its endorsement, recommendation, or favoring by the United States Government or any agency thereof. The views and opinions of authors expressed herein do not necessarily state or reflect those of the United States Government or any agency thereof. 


\section{DISCLAIMER}

Portions of this document may be illegible in electronic image products. Images are produced from the best available original document. 


\title{
Nitrogen and Carbon Oxides Chemistry in the HRS Retorting Process
}

\author{
John G. Reynolds \\ University of California \\ Lawrence Livermore National Laboratory \\ P. O. Box 808, L-365 \\ Livermore, California 94551
}

\begin{abstract}
Average gas concentrations of selected gas phase species were determined from data measured at several places on the combustion system of the Lawrence Livermore National Laboratory Hot-Recycled-Solids Retort Pilot Plant for representative rich and lean shale runs. The data was measured on-line and in real time by on-line meters $\left(\mathrm{CO}_{2}, \mathrm{CO}, \mathrm{O}_{2}\right.$, and $\left.\mathrm{NO}\right)$, mass spectrometry $\left(\mathrm{CO}_{2}, \mathrm{O}_{2}\right.$, $\mathrm{H}_{2} \mathrm{O}, \mathrm{NO}, \mathrm{CH}_{4}, \mathrm{SO}_{2}, \mathrm{~N}_{2}$ and $\mathrm{Ar}$ ), and Fourier transform infrared spectroscopy $\left(\mathrm{CO}_{2}, \mathrm{CO}, \mathrm{H}_{2} \mathrm{O}\right.$, $\mathrm{NO}, \mathrm{N}_{2} \mathrm{O}, \mathrm{NO}_{2}, \mathrm{CH}_{4}, \mathrm{SO}_{2}, \mathrm{NH}_{3}$, and $\mathrm{HCN}$ ).

For both the rich and leans shale runs, the Lift-Pipe Combustor (LFT) exhibited gas concentrations (sampled at the exit of the LFT) indicative of incomplete combustion and oxidation; the DelayedFall Combustor (DFC) exhibited gas concentrations (sampled at the annulus and the exit of the DFC) indicative of much more complete combustion and oxidation. The Fluidized-Bed Combustor exhibited gas concentrations which were controlled to a large extent by the injection atmosphere of the FBC. High levels of nitrogen oxides and low levels of $\mathrm{CO}$ were detected when full air injection was used, while high levels of $\mathrm{CO}$ and low levels of nitrogen-oxides were detected with partial $\mathrm{N}_{2}$ injection.
\end{abstract}

Sequential sampling limitations and nitrogen balances are also discussed.

\section{INTRODUCTION}

The Hot Recycle Solids (HRS) Oil Shale Retort process developed at Lawrence Livermore $\mathrm{Na}$ tional Laboratory (LLNL) consists of a pyrol$y$ sis section which converts kerogen of the shale to liquid and gaseous products, and a combustion section which burns residual carbon on the shale to heat the process. ${ }^{1}$ Figure 1 shows a diagram of the retort in the configuration used for these experiments. The pyrolyzing section is a gravity-fed single stage unit which operates in the range of $500-550^{\circ} \mathrm{C}$. The combustion section has been divided into four sequential units, the Lift Pipe (LFT), the Classifier (CLS), the Delayed-Fall Combustor (DFC), and the Fluidized-Bed Combustor (FBC). In the LFT, combustion is initiated, continuing in the CLS and DFC, and completing (if desired) in the FBC (gas block isolates the FBC). Both the LFT and the FBC have gas-injection ports to control oxygen content and flow. After the FBC, some of the hot combusted shale is collected in the spent hopper, while the rest is mixed with fresh, incoming shale in the Fluidized-Bed Mixer (FBM). There, heat transfer occurs and the fresh shale is heated to pyrolyzing temperatures.

As expected in hydrocarbon-combustion processes, carbon oxides are produced in the combustion gas effluent. In addition, because of high $N$ content in the Green River oil shale ${ }^{2}$ (which is the typical feedstock), nitrogen oxides are also produced in the combustion cycle. Knowledge of the concentrations of these species is important in the design and operation of the retorting process. Carbon oxides are critical in determining mass balances, combustion mechanisms and rates, and are distinctive 
in helping study process parameter variations. Nitrogen oxides are important in understanding fuel nitrogen oxidation chemistry and mechanisms. Both are potentially important as environmentally sensitive components of the flue gas. Further knowledge of the nitrogen oxidation chemistry will be important if abatement is necessary ${ }^{3}$.

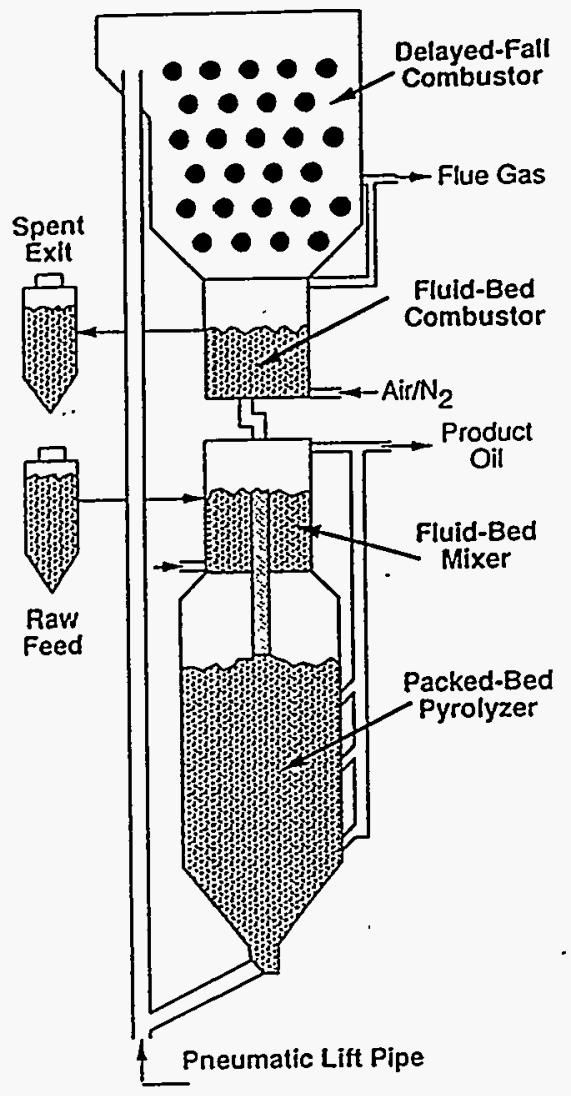

Figure 1. Diagram of the Lawrence Livermore National Laboratory Hot-Recycled Solids Retorting Process.

Table 1 shows average flue-gas emission concentrations for the HRS retorting process, as well as Federal standards for flue gas emissions. ${ }^{4,5}$ The HRS retort concentrations were measured by on-line FTIR spectroscopy and are ranges of concentrations determined over several runs. Because there are no U. S. standards set for Oil Shale retorting processes, the maximum allowed concentrations are listed for industrial boilers for $\mathrm{SO}_{2}$ and $\mathrm{NO}_{\mathrm{x}}$ concentrations, and industrial coke burners for $\mathrm{SO}_{2}$ and $\mathrm{CO}$ concentrations. Clearly, $\mathrm{SO}_{2}$ emissions from the HRS process flue gas are well below any levels needing regulation. The retort can be operated in such a manner that $\mathrm{NO}_{\mathrm{x}}$ is close to compliance with levels set for industrial boilers. $\mathrm{CO}$, however, is considerably higher than standards set for coke burners. Whether the current average emission levels from the HRS retort are sufficient to meet flue-gas emission standards for Oil Shale retorting processes when (and if) they are set, remains to be seen. However, knowledge of these levels will be extremely important. To support this goal, this manuscript reports the concentrations of carbon and nitrogen oxides in various places along the combustion system of the HRS retorting process for typical retort runs at different conditions, and discusses some of the overall chemistry occurring.

\begin{tabular}{|c|c|c|c|}
\hline Component & $\begin{array}{l}\text { Concentration } \\
\text { Ranges } \\
\text { Measured }\end{array}$ & $\begin{array}{l}\text { Maximum } A \\
\text { Boilers }^{b}\end{array}$ & $\begin{array}{c}\text { Allowed Based on: } \\
\text { Coke Burners }\end{array}$ \\
\hline $\mathrm{SO}_{2}$ & 10 to $30 \mathrm{ppm}$ & $370 \mathrm{ppm}$ & $250 \mathrm{ppm}$ \\
\hline $\mathrm{NO}_{x}$ & 250 to $850 \mathrm{ppm}$ & $220 \mathrm{ppm}$ & - \\
\hline co & 1000 to $3000 \mathrm{ppm}$ & $\mathbf{n}$ & $500 \mathrm{ppm}$ \\
\hline
\end{tabular}

Table 1. Concentration ranges of $\mathrm{SO}_{2}, \mathrm{NO}_{x}$, and $\mathrm{CO}$ for the HRS Retort and Federal Emission Standards for Industrial Boilers and Coke Burners

\section{EXPERIMENTAL}

The combustion gases were sampled from the HRS retort directly (for flue gas) or through dust filters (all other ports) to inhibit plugging in the sampling lines due to dust. Calibration for all gases species detected except $\mathrm{H}_{2} \mathrm{O}$ was accomplished by means of commercial gas standards and air. All instruments were connected to the retort gas sampling line by heated $\left(150^{\circ} \mathrm{C}\right) 304$ stainless steel lines.

On-line meters (OLM). $\mathrm{CO}_{2}$ and $\mathrm{CO}$ concentrations were measured by Horiba model PIR-2000 gas meters. NO concentrations were measured by a Horiba model CFA - 311A gas meter. $\mathrm{O}_{2}$ was measured by a Teladyne Analytical Instruments $326 \mathrm{RA}$ gas meter equipped with an A5 microfuel cell.

Mass Spectrometry $(M S) . \mathrm{CO}_{2}(\mathrm{~m} / \mathrm{z} 44), \mathrm{NH}_{3}$ $(\mathrm{m} / \mathrm{z} 17)$, NO $(\mathrm{m} / \mathrm{z} 30), \mathrm{N}_{2}(\mathrm{~m} / \mathrm{z} 28), \mathrm{H}_{2}(\mathrm{~m} / \mathrm{z}$ 2), $\mathrm{O}_{2}(\mathrm{mz} / 32), \mathrm{H}_{2} \mathrm{O}(\mathrm{m} / \mathrm{z} 18), \mathrm{Ar}(\mathrm{m} / \mathrm{z} 40)$, $\mathrm{SO}_{2}(\mathrm{~m} / \mathrm{z} 64)$, and $\mathrm{CH}_{4}(\mathrm{~m} / \mathrm{z} 16)$ concentrations were measured by an EXTREL 
Questor model mass spectrometer. $\mathrm{NH}_{3}$ was corrected for $\mathrm{H}_{2} \mathrm{O} ; \mathrm{CH}_{4}$ was corrected for $\mathrm{H}_{2} \mathrm{O}$ and $\mathrm{NH}_{3} ; \mathrm{N}_{2}$ was corrected for $\mathrm{CO}_{2}$ fragmentations. Data was taken every 10 to 15 sec. Because both $\mathrm{N}_{2} \mathrm{O}$ and $\mathrm{CO}_{2}$ have the same mass to charge ratios ( $\mathrm{m} / \mathrm{z} 44)$, they can not be differentiated in the mass spectrometer. $\mathrm{No} \mathrm{NO}_{2}$ was observed because it fragments entirely into $\mathrm{NO}$ in the mass spectrometer.

Whenever $\mathrm{NH}_{3}$ and $\mathrm{O}_{2}$ were passed into the mass spectrometer, $\mathrm{H}_{2} \mathrm{O}$ and $\mathrm{N}_{2}$ were observed as products. The ratio of $\mathrm{H}_{2} \mathrm{O}$ to $\mathrm{N}_{2}$ indicated approximately $20 \%$ of the $\mathrm{NH}_{3}$ was combusted in the hot MS source. This side reaction was accounted for by measuring a baseline concentrations of these species before each run.

\section{Fourier Transform Infrared Spectrometer}

(FTIR). The gas concentrations were measured by a Bio-Rad FTS-40 equipped with a gas cell ( 6 meter path length) having $\mathrm{NaCl}$ windows. With the appropriate baseline and interfering species corrections, the species were measured at the following locations (in $\mathrm{cm}^{-1}$ ): $\mathrm{CO}_{2}, 2391-2420$; $\mathrm{CO}, 2126-2137$; NO, 1900; $\mathrm{N}_{2} \mathrm{O}, 1240-1285 ; \mathrm{NO}_{2}, 1586-1617 ; \mathrm{H}_{2} \mathrm{O}$, $3911-3967 ; \mathrm{SO}_{2}, 1367-1402, \mathrm{NH}_{3} ; 866-870$; HCN, 3339-3352.

Data Handling. Output from the meters went directly to an HP-1000 data logging system. Output from the MS was reduced to ASCI II format by the Questor system software, and downloaded onto the HP-1000 data tracking system. Output from the FTIR was reduced to ASCI II format by the Unix based software system and downloaded onto the HP-1000 data tracking system.

Average values were calculated based on the data obtained during the time the instruments were sampling a particular port. Only the data was used which appeared to be at or close to a steady state. Because of the configuration of only sequential sampling of ports, the retort was not necessarily at exactly the same conditions for the sampling of each port.

\section{RESULTS}

On-Line Gas Sampling. The combustion gas concentrations were measured on-line in real time by three different techniques -- Online meters, mass spectrometry, and Fourier transfer infrared spectroscopy. Several species were measured by more than one technique, allowing for internal checks of analytical reliability. $\mathrm{CO}_{2}$ was measured by all three instruments. Generally, the FTIR gave results which were consistently over $10 \%$ higher than the OLM or MS. As a result, absolute $\mathrm{CO}_{2}$ concentrations were taken from either OLM or MS data (although the same trends were seen in the FTIR data). NO was also measured by all three instruments. Generally, the MS gave results which were consistently $5 \%$ higher than the OLM and FTIR (attributed to fragment contributions from other ions). As a result, absolute NO concentrations were determined by either the OLM or FTIR. $\mathrm{H}_{2} \mathrm{O}$ was measured by MS and FTIR. The values measured by the FTIR were always several percent higher than the MS. Drying the combustion gas using a water trap still yielded water concentrations of $\sim 2 \%$, indicating a baseline problem in the method of determination. $\mathrm{CO}$ was determined by both OLM and FTIR. Because the FTIR response is non-linear at higher concentrations of $\mathrm{CO}(1 \%$ and higher), the OLM was used for high concentrations. However, at very low concentrations, the OLM meter was not sensitive enough, so the FTIR was used exclusively for low concentrations. Both instruments agreed well in the intermediate range. $\mathrm{CH}_{4}$ was determined by $\mathrm{MS}$ and FTIR. In some cases, the MS gave significantly higher concentrations than the FTIR (attributed to fragment contributions due from larger hydrocarbons). $\mathrm{SO}_{2}$ was measured by $\mathrm{MS}$ and FTIR. Because the concentrations of $\mathrm{SO}_{2}$ are so low in most cases, neither method gave data with good standard deviations.

For these studies, the gas streams were sampled at the top of the LFT (Port A), the annulus of the DFC (Port C), the exit of the DFC (Port D), the exit of the FBC (Port E), and the flue gas (Port F). Because of the gas block and separate gas injections, the flue gas is a combination of effluents from the DFC and the FBC.

Figure 2 shows a typical example of $\mathrm{CO}_{2}$ concentration as a function time for an entire run monitored by OLM. All the instruments sample the flue gas (Port F) during start-up, and remain there until the retort reaches a. reasonable steady operation. The port- 
sampling sequence shown is usually (but not necessarily) followed with sampling periods being approximately $30 \mathrm{~min}$. Repeats are attempted only after the entire suite of ports has been sampled. As seen in Figure 2, the concentrations of $\mathrm{CO}_{2}$ can vary from almost 0 (seen only at start-up), to higher than $15 \%$ (full combustion), so the instruments need to be able to detect a wide range of concentrations quantitatively.

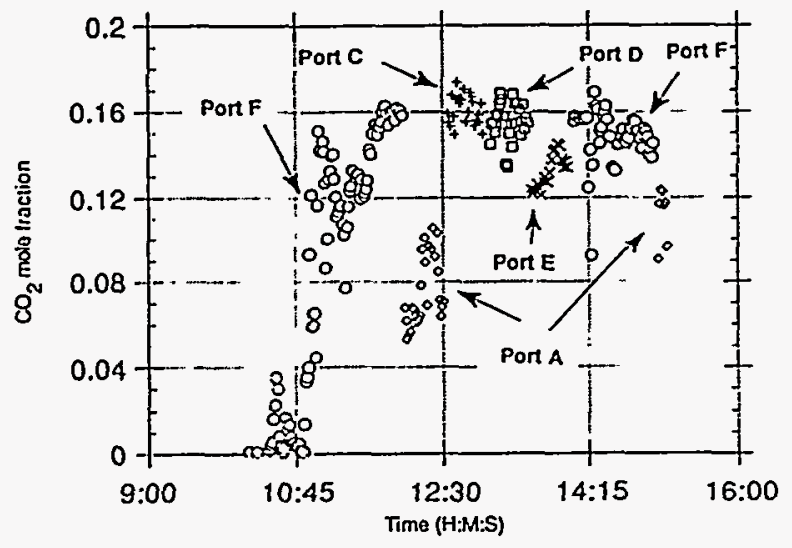

Figure 2. $\mathrm{CO}_{2}$ concentration as a function time for an entire run monitored by OLM.

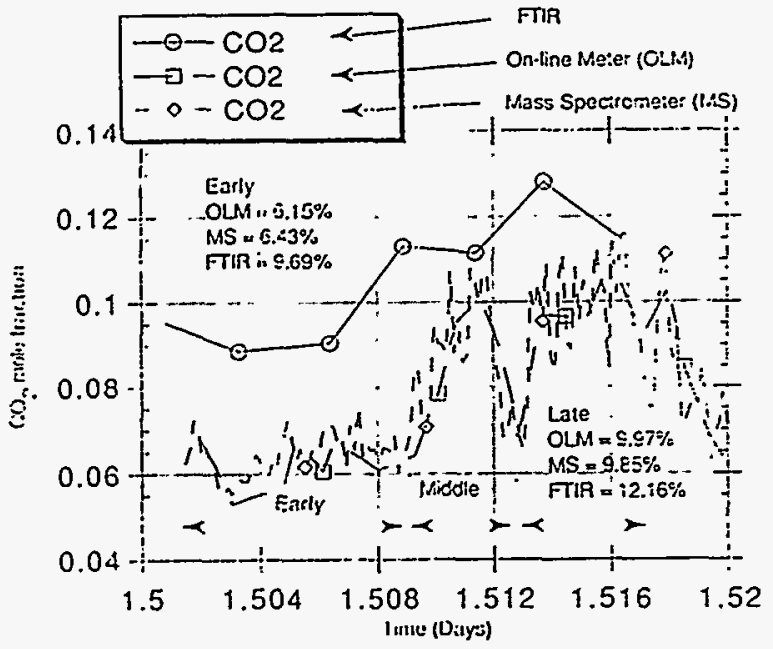

Figure 3. $\mathrm{CO}_{2}$ concentrations determined by on-line meter, mass spectrometry, and FTIR sampled at the top of the LFT:

Figure 3 is a typical example of on-line determination of $\mathrm{CO}_{2}$ concentrations utilizing all three instruments while monitoring the top of the LFT. The agreement between OLM and MS concentrations are excellent, even during changes in conditions ("early" is considered one steady state while "late" is considered another, "middle" is a transition period). The values in the figure are averages over the period limits as delineated by the arrows. These average values for the OLM and MS agree very well, also. The corresponding FTIR concentrations are much higher, even though they parallel the OLM and MS determined concentrations. The average values for the early and late periods also reflect this discrepancy. As mentioned above, this happened consistently in all of our determinations of $\mathrm{CO}_{2}$.

Carbon-Oxide Chemistry. The following diagrams ofuthe HRS have been simplified to only show the combustion side. Included are average concentrations of species relevant to carbon-oxygen chemistry next to the specific port on the diagram. Some ports were not sampled during particular runs. Also included are the average temperatures of the various combustion units during the run from our Run Summary data compilation. These values are averages over yield periods and can vary considerably over a run.

Rich Shale. Figure 4 shows the average concentrations for $\mathrm{CO}, \mathrm{O}_{2}$, and $\mathrm{CO}_{2}$ for a rich shale run. Ports $A, C, E$, and F only were sampled during this run. Clearly, the $\mathrm{CO}_{2}$ and $\mathrm{O}_{2}$ concentrations at the top of the LFT (Port A) indicate combustion is not complete. This high level suggests either incomplete mixing or too short of a residence time. The very high level of $\mathrm{CO}$ also corroborates this incomplete combustion.

The concentration of the species measured at the annulus of the DFC (Port $C$ ) indicate much more complete combustion has occurred in the CLS and the DFC, with higher $\mathrm{CO}_{2}$ levels and much lower $\mathrm{CO}$ and $\mathrm{O}_{2}$ levels.

The FBC gas inlet was operated with full air injection. The average concentrations in the effluent of the FBC (Port E) indicate that some char remained after the spent shale passed from the CLS to the FBC (depleted oxygen level). The high $\mathrm{CO}_{2}$ content suggests that some carbonate decomposition is occurring in addition to the combustion. This is consistent with the high average operating temperature.

The flue gas concentrations (Port F) should be an average of the DFC and $F B C$ concentrations weighted by the LFT and FBC flow rates. 


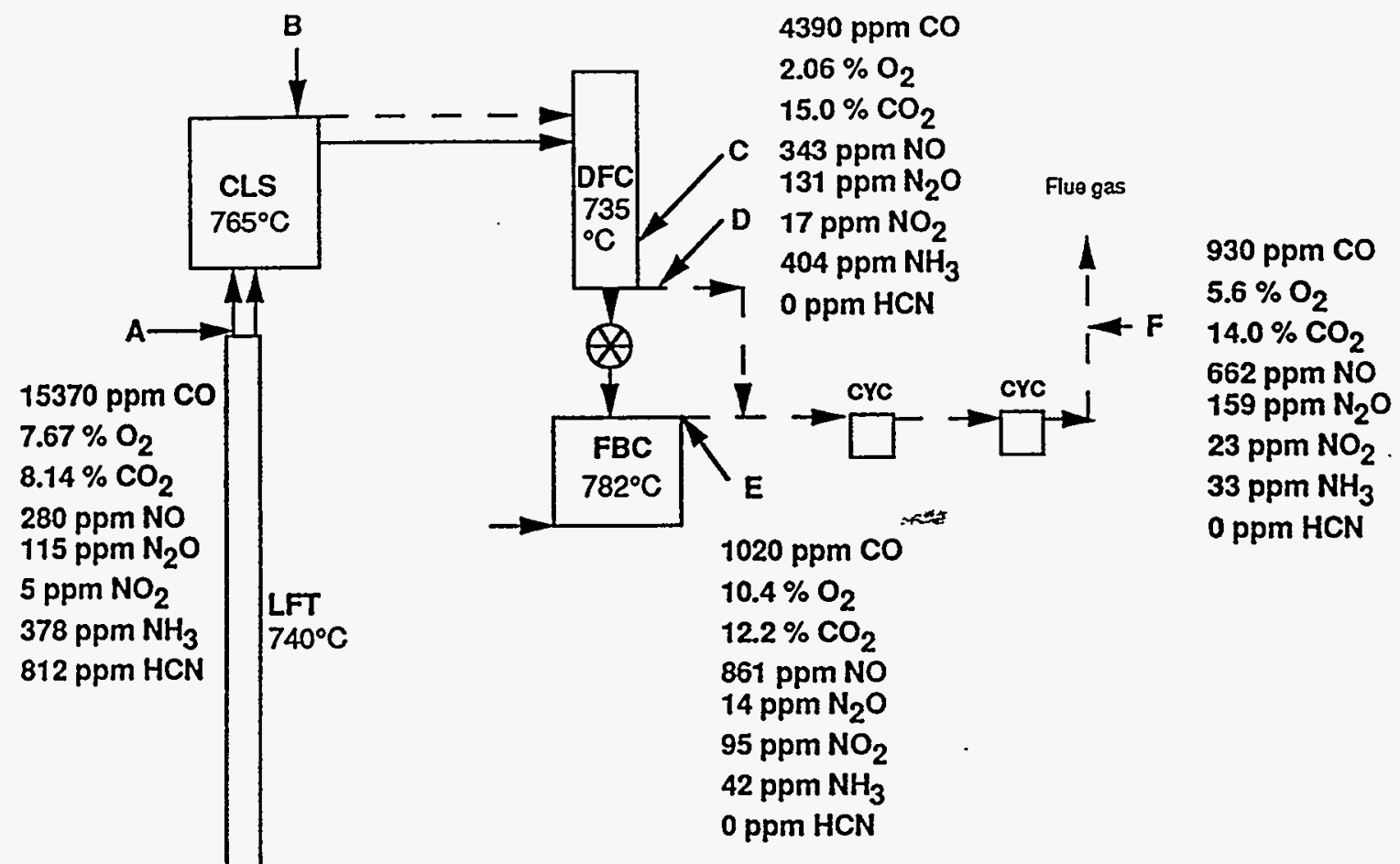

Figure 4. Average concentrations of $\mathrm{CO}, \mathrm{O}_{2}$, and $\mathrm{CO}_{2}$ for a rich shale run.

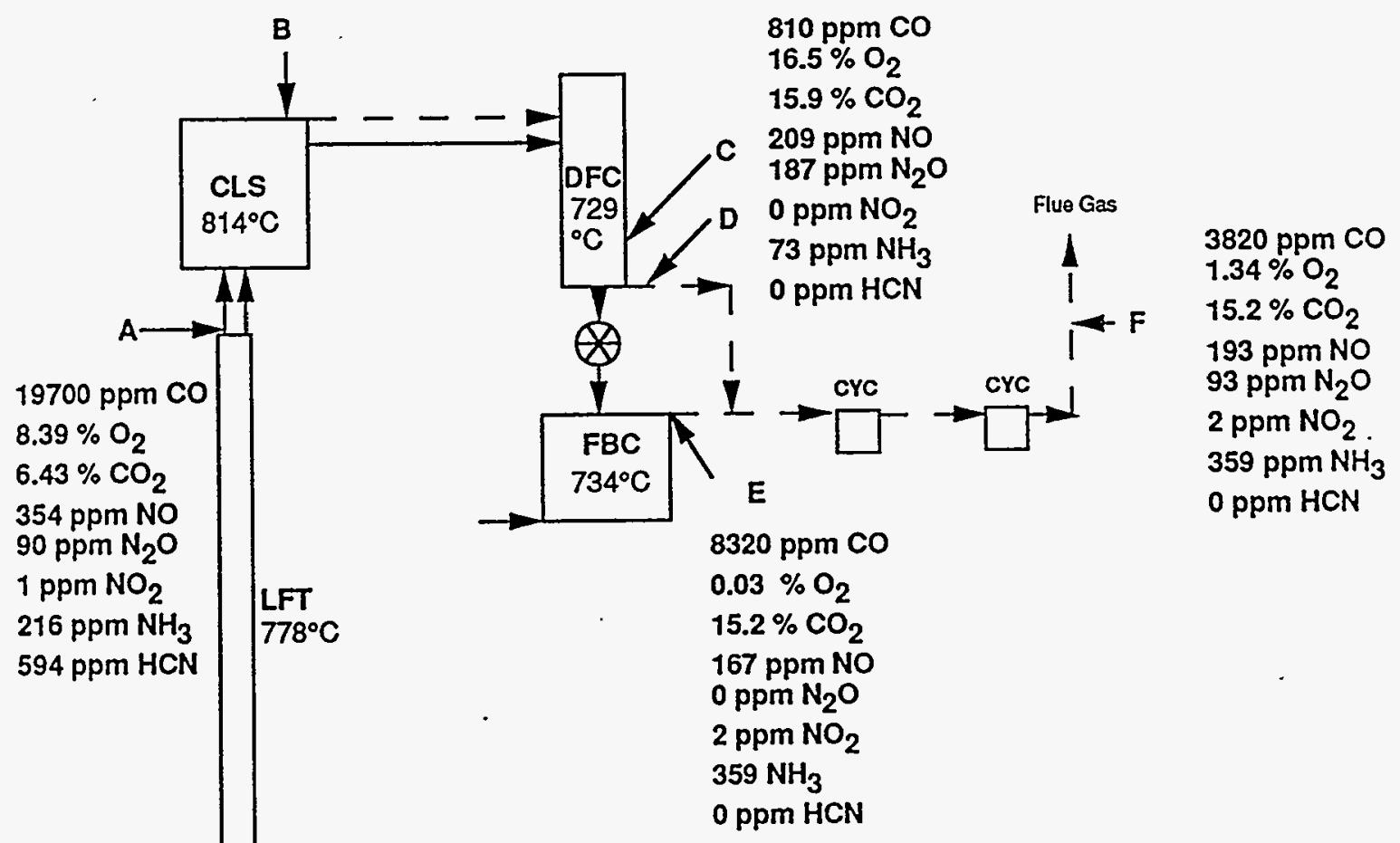

Figure 5. Average concentrations of $\mathrm{CO}, \mathrm{O}_{2}$, and $\mathrm{CO}_{2}$ for a lean shale run 
This is the case for $\mathrm{CO}_{2}$ and $\mathrm{O}_{2}$, but not for $\mathrm{CO}$. This will be discussed in more detail below.

Lean Shale. Figure 5 shows the average carbon-oxide concentrations for a lean shale run. Ports A, B, C, and F only were sampled. The concentrations of gases measured at Port $A$ show, as in the rich shale case, incomplete combustion is occurring in the LFT -- high $\mathrm{O}_{2}$ and $\mathrm{CO}$ levels and relatively low $\mathrm{CO}_{2}$ levels. The concentrations of the gases at the annulus of the DFC (Port C) show that combustion has progressed. Note, the high $\mathrm{O}_{2}$ level in the DFC. This is inconsistent with the lower level in the LFT, but could be a result of sequential sampling.

Unlike the rich shale run, the $\mathrm{FBC}$ was operated on partial air injection. As a result, CO levels are higher than expected with full air injection, but the high $\mathrm{CO}_{2}$ levels indicate considerable char combustion still has occurred. The gas concentrations measured in the flue gas are a weight balance of those concentrations measured for Ports $\mathrm{D}$ and $\mathrm{E}$.

Nitrogen-Oxide Chemistry. The above diagrams also show average concentrations of species relevant to nitrogen oxidation chemistry.

Rich Shale. Figure 4 shows average concentrations of $\mathrm{NO}, \mathrm{N}_{2} \mathrm{O}, \mathrm{NO}_{2}, \mathrm{NH}_{3}$, and $\mathrm{HCN}$ for a rich shale run. Ports $\mathrm{A}, \mathrm{C}, \mathrm{E}$, and $F$ only were sampled. The concentrations of gases measured at the top of the LFT (Port A) show moderate levels of $\mathrm{NO}, \mathrm{N}_{2} \mathrm{O}$, and $\mathrm{NH}_{3}$, low levels of $\mathrm{NO}_{2}$, and very high levels of $\mathrm{HCN}$. The very low level of $\mathrm{NO}_{2}$ and high level of HCN indicate that incomplete oxidation is occurring in the LFT. This is in agreement with carbon-oxide behavior shown in Figure 4 which indicates incomplete combustion is also occurring in the LFT.

The gas concentrations measured at the annulus of the DFC (Port $\mathrm{C}$ ) indicate oxidation chemistry has proceeded -- HCN is no longer present, higher levels of $\mathrm{NO}$ and $\mathrm{NO}_{2}$. This is also in agreement with the combustion chemistry occurring from the LFT to the DFC.

The gas concentrations measured at the exit of the $\mathrm{FBC}$ (Port $\mathrm{E}$ ) indicate highly oxidative conditions. -- very high levels of $\mathrm{NO}_{2}$ and $\mathrm{NO}$, low levels of $\mathrm{HCN}, \mathrm{NH}_{3}$, and $\mathrm{N}_{2} \mathrm{O}$. The high concentrations of $\mathrm{NO}_{2}$ and $\mathrm{NO}$ are probably not due all to fuel $\mathrm{N}$ being oxidized, because 1) there is probably not enough $\mathrm{N}$ in the char to produce such high concentrations of $\mathrm{N}$ containing gas species, and 2) the temperature of the FBC is high enough to cause some decomposition of the ammonia-bearing mineral buddingtonite $\left(\mathrm{NH}_{4} \mathrm{AlSi}_{3} \mathrm{O}_{8} \cdot 0.5 \mathrm{H}_{2} \mathrm{O}\right.$ ). ${ }^{6}$ (As the buddingtonite decomposes, the $\mathrm{NH}_{3}$ is easily oxidized to nitrogen oxides such as $\mathrm{NO}_{2}$ and NO.)

The flue gas concentrations measured at Port $F$ are not a very good weight balance of those of the individual gas streams from the FBC (flow $-0.00 \mathrm{~mol} / \mathrm{sec}$ ) and the DFC (flow -0.00 $\mathrm{mol} / \mathrm{sec}$ ). This could be due to additional chemistry occurring in the cyclone gas-solid separation system which precedes Port $F$, or (more likely) because all three ports are not sampled simultaneously.

Lean Shale. Figure 5 shows average concentrations of nitrogen oxides and related species for a lean shale run. Ports A, C. E, and $F$ only were sampled. The concentrations of gases measured at Port A show similar behavior to the gas concentrations measured for Port $\mathrm{A}$ in the rich shale case -- moderate levels of $\mathrm{NO}, \mathrm{N}_{2} \mathrm{O}$, and $\mathrm{NH}_{3}$, low levels of $\mathrm{NO}_{2}$, and very high levels of $\mathrm{HCN}$. The very low level of $\mathrm{NO}_{2}$ and high level of $\mathrm{HCN}$ indicate that incomplete oxidation is occurring in the LFT. This is also in agreement with carbonoxide behavior shown in Figure 5 which indicates incomplete combustion is also occurring in the LFT.

The gas concentrations measured at the annulus of the DFC (Port C) indicate that oxidacion has proceeded significantly, having higher levels of $\mathrm{N}_{2} \mathrm{O}$ and lower levels of $\mathrm{NH}_{3}$ and particularly $\mathrm{HCN}$. The poor $\mathrm{N}$ balance between Por $\mathrm{A}$ and $\mathrm{C}$ will be discussed below.

The NO concentration is relatively low measured at the exit of the FBC (Port E), while the $\mathrm{NH}_{3}$ concentration is relatively high. The reduced availability of $\mathrm{O}_{2}$ due to partial $\mathrm{N}_{2}$ injection accounts for the much reduced $\mathrm{NO}$ and $\mathrm{NO}_{2}$ levels compared to the rich shale case which had full air injection. As indicated above, this is also reflected in $\mathrm{CO}$ 
concentrations from this port. The $\mathrm{NH}_{3}$ level is also very high. The temperature of the FBC is high enough to cause so buddingtonite decomposition, 6 but the concentration of oxygen in the exit of the FBC $(0.03 \%)$ indicates a non-oxidative environment which would cause little oxidation of the $\mathrm{NH}_{3}$ to $\mathrm{NO}_{\mathrm{x}}$.

Except for $\mathrm{NH}_{3}$, the flue-gas concentrations measured at Port $F$ are roughly weight balanced averages of the gas concentrations measure for the DFC (flow - $0.603 \mathrm{~mol} / \mathrm{s}$ ) and for the FBC (flow $-0.441 \mathrm{~mol} / \mathrm{s}$ ). The $\mathrm{NH}_{3}$ is much higher than calculated $(\sim 150 \%)$. This could be due to additional chemistry occurring in the cyclone gas-solid separation system which precedes Port F, or because of sequential sampling.

Several other runs were examined for nitrogen oxide chemistry. In a lean shale run with full air injection in the FBC, the behavior for each port was similar, except for the FBC where very high levels of $\mathrm{NO}$ and $\mathrm{NO}_{2}$ and low levels of $\mathrm{NH}_{3}$ were measured, consistent with the rich shale run.

\section{DISCUSSION}

A particular problem with monitoring a large scale apparatus is instantaneous sampling at every point of interest. With on-line capabilities, we can obtain momentary changes in gas chemistry as well as average compositions. However, because of the expense of the equipment utilized for these measurements, we are limited to recording data from each port sequentially. For example, in our normal sampling sequence, the annulus of the DFC is sampled one hour after top of the LFT. Any changes in conditions during that time could cause the overall chemistry to be different for sampling Port A than Port C. This must be accounted for when comparing average values of each port, and is one of the major limitations of our analyses. This could cause comparisons of data (possibly taken under different conditions) which would hide process parameter effects, and complicate mass balances. To examine how much this can be a problem, the flue-gas (Port F) compositions were examined in more detail. Because of the combination of gas streams, Port F must be a weighted average of concentrations in Ports $C$ and $E$. If the above sequential sampling is not much of a problem, then the weighted average of Ports $\mathrm{C}$ and $\mathrm{E}$ should be relatively close to average concentrations of Port $F$. This assumes, of course, that no additional combustion or oxidation chemistry is occurring in the cyclones on the flue gas system.

\begin{tabular}{|c|c|c|c|}
\hline Retort Run & Gas & Calculateda & Measuredb \\
\hline Lean & $\begin{array}{l}\mathrm{CO}, \mathrm{ppm} \\
\mathrm{O}_{2}, \% \\
\mathrm{CO}_{2,}, \%\end{array}$ & $\begin{array}{l}697=766 \\
5.27-5.70 \\
15.29-15.71\end{array}$ & $\begin{array}{l}650-848 \\
5.37-5.43 \\
15.35-15.60\end{array}$ \\
\hline Lean & $\begin{array}{l}\mathrm{CO}, \mathrm{ppm} \\
\mathrm{O}_{2, \%} \\
\mathrm{CO}_{2, \%}\end{array}$ & $\begin{array}{l}2880-4244 \\
0.81-0.82 \\
14.85-15.98\end{array}$ & $\begin{array}{l}3560-3820 \\
0.29-1.34 \\
15.15-16.58\end{array}$ \\
\hline Rich & $\begin{array}{l}\mathrm{CO}, \mathrm{ppm} \\
\mathrm{O}_{2, \%} \% \\
\mathrm{CO}_{2,} \%\end{array}$ & $\begin{array}{l}1973 \\
9.63 \\
14.86 \\
\end{array}$ & $\begin{array}{l}1988-2690 \\
6.42-6.73 \\
14.31-14.86 \\
\end{array}$ \\
\hline Rich & $\begin{array}{l}\mathrm{CO}, \mathrm{ppm} \\
\mathrm{O}_{2, \%} \% \\
\mathrm{CO}_{2,} \%\end{array}$ & $\begin{array}{l}3056 \\
5.36 \\
13.86\end{array}$ & $\begin{array}{l}930 \\
5.60 \\
14.00\end{array}$ \\
\hline
\end{tabular}

Table 2. Flue gas compositions for selected retort runs.

Table 2 shows $\mathrm{CO}, \mathrm{O}_{2}$, and $\mathrm{CO}_{2}$ concentrations of the flue gas for selected retort runs. The calculated values are from the weighted averages (based on flow rates) calculated from the average concentrations determined from data measured at the exits of the DFC and FBC. . The range of values in the table is a result of ports being sampled more than once. The highest and lowest values were selected for the limits of the range.

In general, the calculated values fall within the range of the measured values, indicating that the sequential sampling of the ports is sufficient to accurately record the combustion gas chemistry. $\mathrm{CO}_{2}$ and $\mathrm{O}_{2}$ are close in all cases in the table (except for the $\mathrm{O}_{2}$ value in the first rich shale listing). However, $\mathrm{CO}$ shows significant variation in the ranges calculated and measured, as well as a big disagreement between calculated and measured for the second rich shale run in the table. The is probably due to sequential sampling. However, $\mathrm{CO}$ determinations were not as consistent as other species monitored.

The oxidation of fuel $\mathrm{N}$-containing compounds is an extremely complicated process. ${ }^{7}$ All the mechanistic steps have not been determined, but the oxidation appears to go through a sequence which involves $\mathrm{HCN}, \mathrm{N}_{2} \mathrm{O}, \mathrm{NO}$, $\mathrm{NO}_{2}$, and others. Reaction pathways are complicated and can interconnect. In addition, 
in Green River oil shale combustion, $\mathrm{NH}_{3}$ oxidation must be accounted for, whether it is from the fuel $\mathrm{N}$ oxidation pathway or from decomposition of Buddingtonite: $\mathrm{NH}_{3} \mathrm{NO}$.

Run Unit NO $\mathrm{N}_{2} \mathrm{O} \mathrm{NO}_{2} \mathrm{NH}_{3} \mathrm{HCN}$ Total $\mathrm{Neq}_{\mathrm{eq}}$

\begin{tabular}{|c|c|c|c|c|c|c|c|}
\hline $\begin{array}{l}\text { Lean } \\
\text { Lean }\end{array}$ & $\begin{array}{l}\text { LFT } \\
\text { DFC }\end{array}$ & $\begin{array}{l}211 \\
386 \\
\end{array}$ & $\begin{array}{r}14 \\
307 \\
\end{array}$ & $\begin{array}{l}0 \\
0 \\
\end{array}$ & $\begin{array}{r}281 \\
29 \\
\end{array}$ & $\begin{array}{r}568 \\
0 \\
\end{array}$ & $\begin{array}{l}1088 \\
1020 \\
\end{array}$ \\
\hline $\begin{array}{l}\text { Special } \\
\text { Special }\end{array}$ & $\begin{array}{l}\text { LFT } \\
\text { DFC }\end{array}$ & $\begin{array}{l}354 \\
209 \\
\end{array}$ & $\begin{array}{r}90 \\
187 \\
\end{array}$ & $\begin{array}{l}2 \\
0\end{array}$ & $\begin{array}{r}216 \\
73 \\
\end{array}$ & $\begin{array}{r}594 \\
0 \\
\end{array}$ & $\begin{array}{r}7344 \\
656 \\
\end{array}$ \\
\hline $\begin{array}{l}\text { Rich } \\
\text { Rich }\end{array}$ & $\begin{array}{l}\text { LFT } \\
\text { DFC }\end{array}$ & $\begin{array}{l}280 \\
343\end{array}$ & $\begin{array}{l}715 \\
131\end{array}$ & $\begin{array}{r}5 \\
17 \\
\end{array}$ & $\begin{array}{l}378 \\
404 \\
\end{array}$ & $\begin{array}{r}812 \\
0 \\
\end{array}$ & $\begin{array}{l}1705 \\
1026\end{array}$ \\
\hline
\end{tabular}

Table 3. Gas-phase nitrogen concentrations (ppm) in Lift Pipe (LFT) and Delayed-Fall Comnbustor (DFC)

Table 3 shows the gas-phase nitrogen concentrations measured for the LFT and the DFC. These concentrations are related because they are determined by sampling the same gas stream at different places. The top lean shale run shows the HCN concentration is high in the LFT but is zero in the DFC. The levels of $\mathrm{NO}$ and $\mathrm{NH}_{3}$ are moderate in the LFT, but increase and decrease, respectively, in the DFC. $\mathrm{N}_{2} \mathrm{O}$ is low in the LFT, but is reasonably high in the DFC. If the $\mathrm{N}$ is redefined as nitrogen equivalents $\left(\mathrm{N}_{\mathrm{eq}}\right)$, that is $1 \mathrm{ppm}$ of NO is $1 \mathrm{ppm} \mathrm{N}$ eq, while $1 \mathrm{ppm} \mathrm{N} \mathrm{N}_{2} \mathrm{O}$ is 2 ppm $N_{e q}$, the total $N_{e q}$ balance is excellent. This suggests the nitrogen-oxygen chemistry is related through the above reactions.

The second lean shale run listed in Table 3 shows similar behavior to the first, except the $\mathrm{NO}$ concentration decreases and the total $\mathrm{N}_{\mathrm{eq}}$ at the annulus of the DFC is about one half of that measured at the top of the LFT. The rich shale run behaves similarly, except the NO decreases, the $\mathrm{NH}_{3}$ increases, and the total $\mathrm{N}_{\mathrm{eq}}$ measured at the annulus of the DFC is significantly less that measured at the top of the LFT.

This loss of nitrogen in the latter two listed runs could be a result of sequential sampling as discussed above. However, the carbon-oxide chemistry shows that sequential sampling may not a problem (at least in the cases mentioned when comparing Ports $\mathrm{C}, \mathrm{E}$, and F). Another possibility is that some type of NO reduction chemistry is occurring in the LFT-CLS-DFC system. These possible types are: Thermal deNO ${ }_{x}$, selective catalytic reduction (SCR), and char reduction. Reaction 1 shows the generally recognized reaction for thermal and catalytic NO reduction and reactions 2 and 3 show the char reduction reactions, with and without $\mathrm{O}_{2}$.

$$
\begin{aligned}
& \mathrm{NO}+\mathrm{NH}_{3}+1 / 4 \mathrm{O}_{2} \\
& \mathrm{CH}_{\mathrm{x}}+\mathrm{O}_{2}+\mathrm{NO}+3 / 2 \mathrm{H}_{2} \mathrm{O} \\
& \mathrm{CH}_{\mathrm{x}}+\mathrm{NO}(?)+\mathrm{CO}_{2}+\mathrm{H}_{2} \mathrm{O} \\
& \mathrm{N} 2(?)+\mathrm{CO}_{2}+\mathrm{H}_{2} \mathrm{O}
\end{aligned}
$$

We have shown in laboratory studies, combustedoil shale ${ }^{3}$ as well as residual char on shale 3,8 are capable of reducing NO. Further testing is necessary to deconvolute the origin of this imbalance.

\section{CONCLUSIONS}

Several general conclusions can be made about behavioral trends of the combustion gas system:

- LFT exhibits incomplete combustion and oxidation chemistry -- high level of $\mathrm{CO}(\sim$ $1.5 \%)$, lower levels of $\mathrm{CO}_{2}(\sim 9 \%)$, residence time or mixing limited $\left(\mathrm{O}_{2}\right.$ available), high levels of $\mathrm{HCN}$ ( 500 to $10000 \mathrm{ppm}$ ), and low levels of $\mathrm{NO}_{2}$.

- DCF exhibits more complete combustion and oxidation -- dramatic decrease in $\mathrm{CO}$, most $\mathrm{O}_{2}$ consumed ( $\sim 2 \%$ residual in some cases), and a dramatic decrease in $\mathrm{HCN}$.

- FBC exhibits $\mathrm{CO}$ and $\mathrm{NO}_{x}$ concentrations which depend upon injection atmosphere -excess air yields low $\mathrm{CO}$ and high $\mathrm{NO}_{\mathrm{x}}$, and limited air yields low $\mathrm{NO}_{\mathrm{x}}$ and high $\mathrm{CO}$.

- Poor $N$ closure is seen in some runs suggesting the possibility of NO reduction chemistry.

\section{ACKNOWLEDGMENTS}

I thank Clarence J. Morris and Douglas B. Fields for contributing the collection of the gas analyses data, Robert J. Cena for allocating funding. The work was performed under the auspices of the U. S. Department of Energy by the Lawrence Livermore National Laboratory under contract no. W-7405-ENG-48. Parts of the work were performed under a CRADA including Chevron, Amoco, UNOCAL. and Conoco Companies. 


\section{REFERENCES}

1. R. J. Cena and C. B. Thorsness, Lawrence Livermore, National Laboratory Report, UCRL-JC-109241 (April 17, 1992).

2. J. G. Reynolds, R. W. Crawford, and

A. K. Burnham, Energy and Fuels, 5, 507-523 (1991).

3. J. G. Reynolds, R. W. Taylor, and C.

J. Morris, Fuel, 72, XXXX (1993).

4. Code of Federal Regulations, volume

40, parts 53-60.

5. Federal Regulation 60.103 and 60.104

for Petroleum Refineries, Catalytic

Cracking.

6. M. S. Oh, K. G. Foster, A. Alcaraz,

R. W. Crawford, R. W. Taylor, and T. T.

Coburn, Fuel, 517-523 (1993).

7. J. A. Miller and C. T. Bowman, Prog.

Energy Combust. Sci., 15, 287-338 (1989).

8. R. W. Taylor and C. J. Morris, ACS

Div. Fuel Chem., Preprints, 29(3), 277-283

(1984).

\section{FIGURE LEGENDS}

Figure 1. Diagram of the Lawrence

Livermore National Laboratory Hot-Recycled

Solids Retorting Process.

Figure 2. $\mathrm{CO}_{2}$ concentration as a function time for an entire run monitored by OLM.

Figure 3. $\mathrm{CO}_{2}$ concentrations determined by on-line meter, mass spectrometry, and FTIR sampled at the top of the LFT.

Figure 4. Average concentrations of $\mathrm{CO}$, $\mathrm{O}_{2}$, and $\mathrm{CO}_{2}$ for a rich shale run.

Figure 5. Average concentrations of $\mathrm{CO}, \mathrm{O}_{2}$, and $\mathrm{CO}_{2}$ for a lean shale run 